\title{
Analysis Of The Influence Of Customer Satisfaction On Sharia Banking Peroformance In Bogor City
}

\author{
R Dina Arfiana Burhan ${ }^{1}$, Muhammad Najib ${ }^{2}$, Endri $^{3}$ \\ ${ }^{1,2,3}$ Institut Agama Islam Tazkia \\ * Corresponding Author: \\ Email: dina.arfiana@gmail.com
}

\begin{abstract}
.
The development of Islamic banking is very rapid, causing competition

between Islamic and conventional banking. Improving the quality of services and products makes the main point in providing customer satisfaction. This study aims to analyze the influence of service quality, product quality, and price with customer satisfaction at Islamic commercial banks in the city of Bogor. This study uses SEM (Structural Equation Modeling) to determine the level of influence of the relationship between customer satisfaction with service quality, product quality and price. This study used a sample of 100 respondents with qualifications of 81 men and 19 women and used a descriptive approach. The results of this study are the level of customer satisfaction with prices reaching 2.49 , besides that the level of customer satisfaction with products is 2.91, and the level of customer satisfaction with service quality is 2.84. These results prove that customer satisfaction is strongly influenced by the price, products, and quality of services provided by Islamic banking.

Keywords: Service quality, Products, Prices, SEM (Structural Equation Modeling), Islamic Banking.
\end{abstract}

\section{INTRODUCTION}

In terms of service providers, Islamic banking is different from conventional banking. The fundamental difference between Islamic banks and conventional banks lies in the practice of running their business, where operations are based on sharia principles, and this principle is the high attraction for customers to take advantage of Islamic banking services. Profit-oriented business entities, Islamic banks are required not only to seek profit (profit oriented) without considering the function and insight as a sharia business entity based on the concepts of Al Quran and Al sunnah (maqasid syari'ah). As an intermediary institution, Islamic banks participate in channeling public funds and channeling them to the real sector with a combination of products offered in accordance with sharia [1].

According to Ngatmo [2], one of the factors that influence customer satisfaction is the customer's perception of service quality. Customer satisfaction, apart from being influenced by service quality, is also determined by product quality, value, price and other personal and instantaneous factors. Based on this, service quality is very important in a company, especially in the service sector, namely banking. In addition, service quality in banking is one of the factors that influence customer satisfaction. Therefore, banks are required to improve the quality of services.

Islamic banks use principles based on Islamic law in implementing rules and agreements in banking activities. Pricing at a bank aims to allow banks to dominate the market, increase profits, and survive in the banking world. Banks should be closer to customers with a variety of business approaches, for example setting attractive interest rates. Interest rates relate to products owned by banks, interest rates here act as prices. Currently, many customers want to get cheap loans from banks, so customers will look for loans with low interest rates. While customers are looking for the most profitable savings, they will look for savings with high interest rates. 
Table. 1. Total Assets, Number of Offices, and Sharia Banking Workforce

\begin{tabular}{|c|c|c|c|c|c|c|}
\hline \multirow{2}{*}{\multicolumn{2}{|c|}{ Indikator }} & \multirow{2}{*}{2014} & \multirow{2}{*}{2015} & \multirow{2}{*}{2016} & \multirow{2}{*}{2017} & \multirow{2}{*}{$\begin{array}{c}2018 \\
\text { Des }\end{array}$} \\
\hline & & & & & & \\
\hline \multicolumn{7}{|c|}{ Bank Umum Syariah } \\
\hline- & Total Aset & 204,961 & 213,423 & 254.184 & 288.027 & 316.097 \\
\hline- & Jumlah Bank & 12 & 12 & 13 & 19 & 4 \\
\hline$\overline{-}$ & Jumlah Kantor & 2,163 & 1.901 & 1.869 & 1.825 & 1.875 \\
\hline$=$ & Jumlah Tenaga Kerja & 41,38 & 51.413 & 51.110 & 51.668 & 49516 \\
\hline \multicolumn{7}{|c|}{ Unit Usaha Syariah } \\
\hline- & Total Aset & 57,39 & 82,830 & 102,320 & 136.154 & 160636 \\
\hline- & $\begin{array}{l}\text { Jumlah Bank Umum } \\
\text { Konvensional yang memiliki } \\
\text { UuS }\end{array}$ & 22 & 22 & 21 & 21 & 20 \\
\hline- & Jumlah Kantor UU'S & 320 & 371 & $3 \sqrt{32}$ & 344 & 354 \\
\hline- & Jumlah Tenaga Kerja & 4.425 & 4,403 & 4.497 & 4.678 & 4.95 \\
\hline \multicolumn{2}{|c|}{ Total Aset BUS dan UUS } & 272,343 & 296,262 & 356,504 & 424,181 & 477,327 \\
\hline \multicolumn{2}{|c|}{ Total Kantor Bus dan UUS } & 2,483 & 2,301 & 2,201 & 2,169 & 2.229 \\
\hline \multicolumn{2}{|c|}{ Total ATM BUS dan UUS } & 3,482 & 3.716 & 3,259 & 2,728 & 2.962 \\
\hline \multicolumn{2}{|c|}{ Total Tenaga Kerja Bus dan uUs } & 45,818 & 55,816 & 55,597 & 55,746 & 54.477 \\
\hline
\end{tabular}

(Sumber: SPS, 2019)

In the table above, it can be seen that there was an increase in assets from year to year but there was a reduction in the workforce in 2018. This data proves that there is efficiency in Islamic banking management to maintain assets. If we look in more detail, the growth of assets from year to year is not too significant. The growth of Islamic banking can be said to be lacking in developing product innovation for customer service.

Research conducted by Purnaningsih [3] states that the factors that influence customer satisfaction are: location and facilities, flowers, gifts, company image, convenience, service, product fame, and security. Similar to the research conducted by Widiyanto in 2012, the results of his research showed that core service quality variables had a positive and significant effect on customer satisfaction. The relational factor variable has a positive and significant effect on customer satisfaction and the physical aspect variable has a positive and significant effect on customer satisfaction.

Thus it is very important to analyze the variables that affect Customer Satisfaction at Islamic Commercial Banks in the City of Bogor, in order to provide motivation in innovating to make original products according to sharia. This research will be a barometer of Islamic banking in an effort to improve the performance of Islamic banking.

\section{LITERATURE REVIEW}

\section{a. Customer satisfaction}

Achieving the highest level of customer satisfaction is the ultimate goal of marketing. In fact, recently much attention has been paid to the concept of total satisfaction, the implication of which is that achieving only partial satisfaction is not enough to keep customers loyal and come back for more. When customers are satisfied with the service obtained during the transaction process and are also satisfied with the goods or services they get, they are likely to come back and make other purchases and will also recommend to their friends and family about the company and its products. The company will be successful in getting customers in large numbers if it is considered to be able to provide satisfaction for customers. When customers are satisfied, there will be a harmonious relationship between producers and consumers, creating a good basis for repeat purchases and forming word of mouth recommendations that can benefit a company.

Kotler and Keller [4]; Kaniganat \& Chaipoopirutana [5] defined customer satisfaction as an individual's emotions of preference or displeasure measured by comparing a product or service's outcome to expectation. Generally, customers can feel satisfied or dissatisfied after purchasing and consuming goods or services. Satisfaction is the positive feeling a customer will create after buying a good one or receiving a service. The feelings mentioned above will be determined by the interaction of customer expectations and performance. If the goods or services purchased by a customer are measured at the same level of expectations, he or she will be satisfied. If the level of the items purchased or his Service was higher than his expectation, he would be very happy. If this level is lower than expectations, the customer will feel dissatisfied [6](Molaee et al, 2013). 


\section{b. Customer Satisfaction Model}

Customer satisfaction with a service is determined by the level of customer expectations before using the service compared to the results of customer perceptions of the reality of service performance perceived by customers. Sumarwan [7] states that in the disconfirmation paradigm model, customer satisfaction is the impact of the comparison between expectations and reality obtained by customers. Positive confirmation is if the performance of the product or service is better than expected, if this happens, the customer will be satisfied. If the reality is the same as expected, it is called a simple confirmation. If the reality is worse than expected, the customer will feel disappointed and dissatisfied, this is called negative disconfirmation.

Pig 1.Model Kepuasan Pelanggan Paradigma Diskonfirmasi

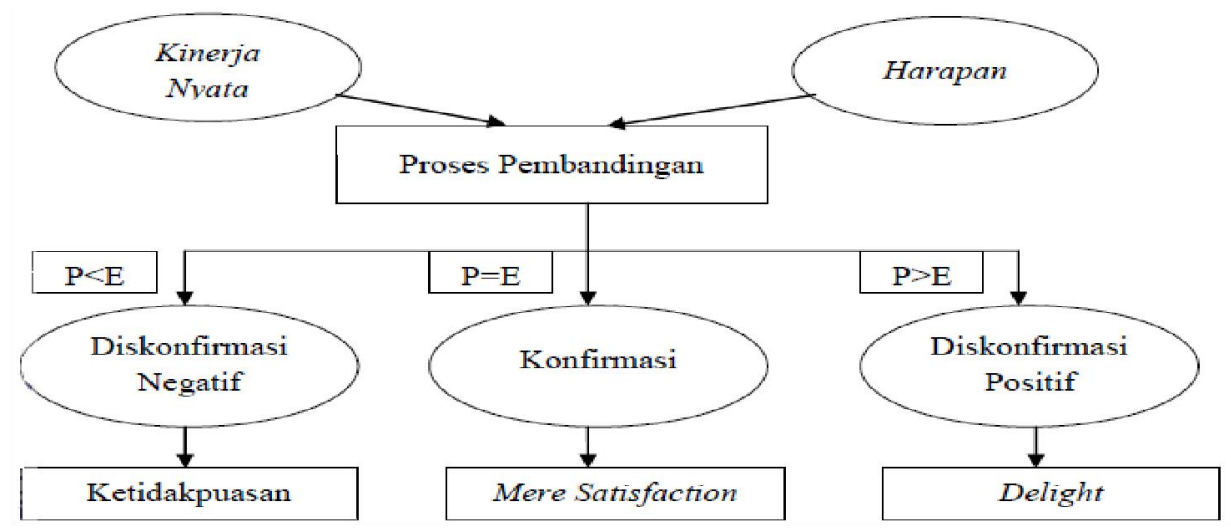

Sumber: Suwarman, et.al. [7]

\section{c. Measurement of customer satisfaction}

According to Kotler [8]; Sarirati \& Fitria [9], there are four methods that can be used to measure customer satisfaction, namely:

1) Complaints and suggestions system

Companies that provide the opportunity for customers to express opinions or even complaints are customer-oriented companies.

2) Customer satisfaction survey:

Every now and then a company needs to conduct a customer satisfaction survey of the quality of the company's services or products. This survey can be carried out by distributing questionnaires by company employees to customers.

3) Ghost Shopping

This method is carried out by hiring several companies (ghost shopping) to act as customers in competing companies, with the aim of the ghost shopping being able to find out the service quality of competing companies so that it can be used as a correction to the service quality of the company itself.

4) Analysis of lost customers

This method is carried out by the company by calling back its customers who have not visited or made another purchase at the company by asking the reasons for moving customers to competing companies.

Customer satisfaction is the level of performance (results) that are felt compared to expectations. With intense competition in the banking system, customer satisfaction is becoming a more important issue in customer marketing [10]. Customer satisfaction can be measured using the following three indicators [11]:

1) Overall satisfaction.

This indicator is the result of evaluation and experience of current consumption stemming from habits, constraints, and service standardization.

2) Confirmation of expectation.

This indicator is the level of conformity between the level of perceived satisfaction and customer expectations.

3) Comparison of ideal.

This indicator represents the product's performance compared to ideal conditions according to customer perceptions. 


\section{c. Previous Research}

Research that discusses the factors that influence customer or customer satisfaction has been conducted several times. The following are some of them:

Research conducted by Kartika [12] contained research variables, namely image (X1), customer satisfaction (X2), customer trust (X3), and customer loyalty (Y). This research method is quantitative. The results of this study indicate that customer trust is a variable that has a positive and significant effect on customer loyalty in Islamic banks. Customer image and satisfaction have a significant effect on customer trust. Image also has a significant effect on customer satisfaction.

Research Panjaitan \& Yuliati [13] there are research variables namely Service Quality (X) and Customer Satisfaction (Y). The results of this study indicate that service quality (X) which consists of reliability, certainty, reality, empathy, and responsiveness, has a significant effect on customer satisfaction. Some of the test results show that only the empathy variable has a partial influence on customer satisfaction.

Noerchoidah's research [14] contained research variables, namely service quality (X) and Customer Satisfaction (Y). And this study uses a questionnaire data collection method. The results showed that the tangible variables, reliability, responsiveness, assurance, and empathy had a simultaneous effect on customer satisfaction in Orenztaxi Surabaya. Tangible, responsiveness, and empathy partially have a positive and significant effect, while reliability and assurance have no significant effect on customer satisfaction at Orenztaxi Surabaya.So the difference between previous research research and research conducted by researchers at this time lies in the object of research conducted at Islamic commercial banks in Bogor City, and this type of research is quantitative, and researchers want to find out the factors that affect customer satisfaction at Islamic commercial banks in Bogor city.

\section{RESEARCH METHODS}

This study uses a descriptive approach with the aim of describing the object of research. According to Sugiyono [15] descriptive method is a method that functions to describe or give an overview of the object under study through data or samples that have been collected as they are without analyzing and making generally accepted conclusions. Research on Customer Satisfaction at Islamic Commercial Banks in Bogor City was conducted in three stages, namely in-depth literature studies on customer satisfaction. Then from the theoretical study, a theoretical framework and hypothesis formulation is made. Then conducted a survey by distributing questionnaires to customers who are respondents. The data from the questionnaire was then analyzed using the PLS-SEM method.

Respondents of this study are the people of the Bogor City area who are customers of Islamic Commercial Banks and Sharia Business Units. The consideration of choosing the city of Bogor is because Bogor has a fairly good growth in Islamic banking in West Java. Islamic banking in the city of Bogor is in the third position with the largest total Third Party Funds and financing provided in West Java Province after Bandung and Bekasi [16]. In obtaining a comprehensive sampling picture, customers will be selected from the 5 largest Sharia Commercial Banks in Bogor with the largest assets in Bogor City, namely Bank Muamalat, Bank Jabar Syariah, BTN Syariah, BRI Syariah and Bank Mega Syariah. Thus the respondents in this study were as many as 100 customers.

\section{SEM (Structural Equation Modelling)}

Multivariate analysis techniques that allow researchers to examine the relationships between complex variables to obtain a comprehensive picture of the overall model. SEM was developed to cover the limitations of models such as: regression analysis, path analysis, and confirmatory factor analysis [18]. 
Fig.1 Model of SEM

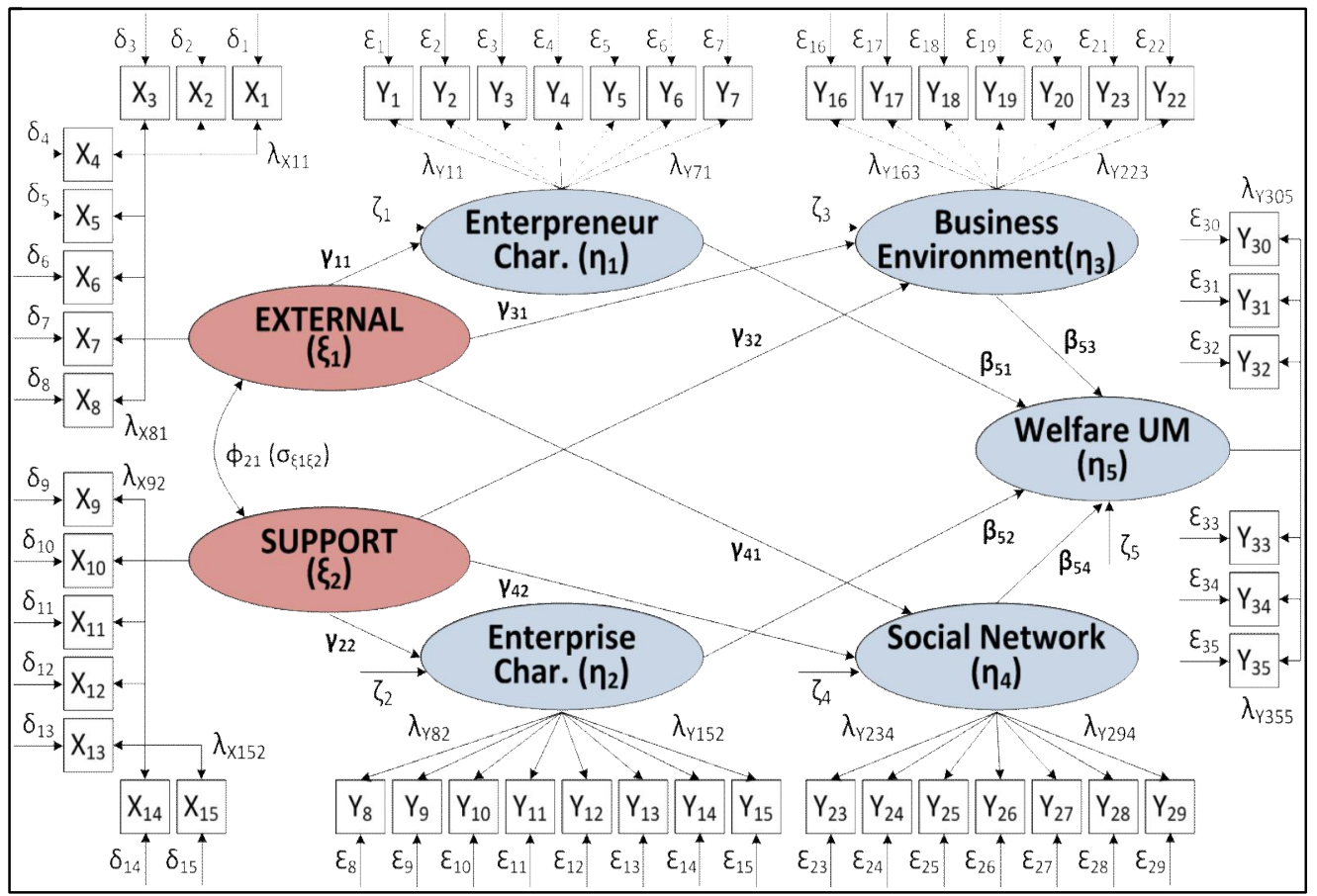

(source: Wijanto, 2008)

\section{RESULTS AND DISCUSSION}

\section{Results of the Descriptive Analysis of Service Quality Variables.}

The results of the average analysis of respondents' answers to each indicator of the Service Quality variable are presented in the following table:

Table 1. Results of the Mean Service Quality Variable Analysis

\begin{tabular}{|l|l|c|}
\hline No & \multicolumn{1}{|c|}{ Indicator } & Mean \\
\hline 1. & Tangibles & 3.25 \\
\hline 2. & Reliability & 3.32 \\
\hline 3. & Responsiveness & 3.31 \\
\hline 4. & Assurance & 3.24 \\
\hline 5. & Emphaty & 3.59 \\
\hline \multicolumn{2}{|c|}{ Overall average } & 3.34 \\
\hline
\end{tabular}

Source: primary data processed, 2018

The table above shows that the overall average respondent's answers to the service quality variable are 3.34. In more detail, the average respondent's answer to the tangibles indicator is 3.25 . The reliability indicator is 3.32 , the responsiveness indicator is 3.31 , the assurance indicator is 3.24 , and the empathy indicator is 3.59.These results indicate that the highest service quality is on the empathy indicator, and the lowest is on the assurance indicator.

\section{Results of the Descriptive Analysis of Product Quality Variables.}

The results of the average analysis of respondents' answers to each indicator of the Product Quality variable are presented in the following table. 
Table 2. Results of the Mean Variable Product Quality Analysis

\begin{tabular}{|c|l|c|}
\hline No & \multicolumn{1}{|c|}{ Indicator } & Mean \\
\hline 1. & Kinerja (Performance) & 3.45 \\
\hline 2. & Features & 3.43 \\
\hline 3. & Reliability & 3.39 \\
\hline 4. & Conformance & 3.62 \\
\hline 5. & Durability & 3.49 \\
\hline 6. & Service ability & 3.54 \\
\hline 7. & Aesthetics & 3.68 \\
\hline 8. & (Perceived quality) & 3.57 \\
\hline \multicolumn{2}{|r|}{ Overall average } \\
\hline
\end{tabular}

Source: primary data processed, 2018

The table above shows that the overall average respondent's answers to the product quality variable are 3.52. In more detail, the average respondent's answers to the performance indicators are 3.45, the features indicators are 3.43 , the reliability indicators are 3.39 , the conformance indicators are 3.62 , the durability indicators are 3.49, the aesthetics service capabilities indicators are 3.68, and the perceived quality indicators are 3.57. These results indicate that the highest product quality is on the Aesthetic indicator, and the lowest is on the Reliability indicator.

\section{Results of the Descriptive Analysis of Price Variables.}

The results of the analysis of the average respondent's answers to each indicator of the price variable are presented in the following table:

Table 4.3 Results of the Mean Price Variable Analysis

\begin{tabular}{|c|l|c|}
\hline No & \multicolumn{1}{|c|}{ Indicator } & Mean \\
\hline 1. & Flexibility & 3.58 \\
\hline 2. & Credit terms & 3.42 \\
\hline 3. & Discounts & 3.47 \\
\hline \multicolumn{2}{|c|}{ Overall average } & 3.49 \\
\hline
\end{tabular}

Source: primary data processed, 2018

The average overall respondent's answers to the price variable are 3.49. In more detail, the average respondent's answers to the flexibility indicator were 3.58, the credit terms indicator was 3.42 , and the discount / discount indicators were 3.47. These results indicate that the highest price is on the indicator of flexibility, and the lowest is on the indicator of credit terms.

\section{Results of the Descriptive Analysis of Customer Satisfaction Variables}

The results of the average analysis of respondents' answers to each indicator of the Customer Satisfaction variable are presented in the following table:

Table.4.4 Results of Analysis of Mean Variable Customer Satisfaction

\begin{tabular}{|c|l|c|}
\hline No & \multicolumn{1}{|c|}{ Indicator } & Mean \\
\hline 1. & Attributes related to product & 3.72 \\
\hline 2. & Attributes related to service & 3.76 \\
\hline 3. & Attributes related to purchase & 3.84 \\
\hline \multicolumn{2}{|c|}{ Overall average } & 3.77 \\
\hline
\end{tabular}

Source: primary data processed, 2018

The average of all respondents' answers to the customer satisfaction variable is 3.77 . In more detail, the average respondent's answer to the Attributes related to product indicator is 3.72, the Attributes related to service indicator is 3.76, and the Attributes related to purchase indicator is 3.84. These results indicate that 
the highest customer satisfaction is on the Attributes related to purchase indicator, and the lowest is on the Attributes related to product indicator.

\section{Test Assumptions and Quality of Research Instruments}

\section{Validity Test}

The validity test uses the Factor Analysis model, what needs to be considered in this test is the Standardize Loading Factor (SLF) value in the Anti Image table and the Extraction Value in the Communalitties table. Questions will be considered valid if they have SLF and Exraction values greater than 0.5.The greater this value, indicating that the constituent indicators for a latent variable are reliable indicators in measuring the latent variable. The suggested construct reliability value is greater than 0.7 .

\section{a. Service Quality Test}

In this test, the message framing variable that has been tested is Chi - Square $=6.94 ; \mathrm{df}=5, \mathrm{P}$-value $=$ 0.225 , RMSEA $=0.073$.

Figure.2 Service Quality Variable Measurement Model

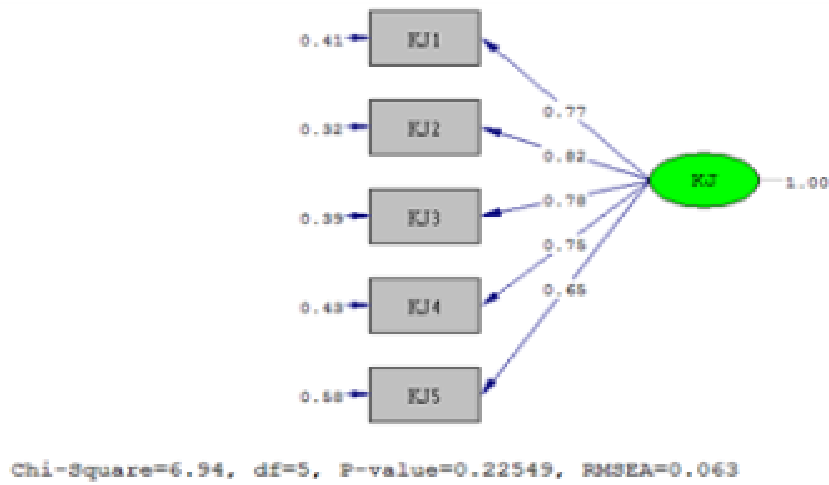

Source: primary data processed, 2018

Table 3. Validity Test of Service Quality Variables

\begin{tabular}{|c|c|c|c|}
\hline Indicator & $\begin{array}{c}\text { SLF (Standardize } \\
\text { Loading Factor) }\end{array}$ & \multirow{2}{\text{Standard}}{$\begin{array}{c}\text { Information } \\
\text { Value }\end{array}$} & \\
\hline KJ1 & 0.77 & \multirow{4}{*}{0.50} & VALID \\
\hline KJ2 & 0.82 & & VALID \\
\hline KJ3 & 0.78 & & VALID \\
\hline KJ4 & 0.75 & & VALID \\
\hline KJ5 & 0.65 & & VALID \\
\hline
\end{tabular}

Source: Data processed with the 2018 Lisrel program

In table 3 above, the five indicators processed in SEM are all valid, in other words all indicators can be used in the research model.

\section{b. Product Quality}

In this test, the variable service quality has been tested by obtaining the results Chi - Square = 18.42; $\mathrm{df}=20, \mathrm{P}$-value $=0.559$, $\mathrm{RMSEA}=0.000$.

Fig 3. Product Quality Variable Measurement Model

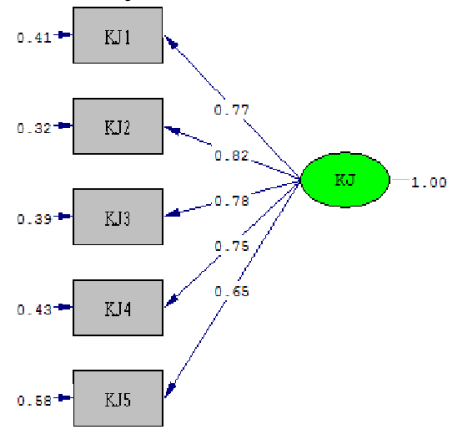

Chi-square $=6.94, \mathrm{df}=5, \mathrm{P}$-value $=0.22549, \mathrm{FMSEA}=0.063$ 


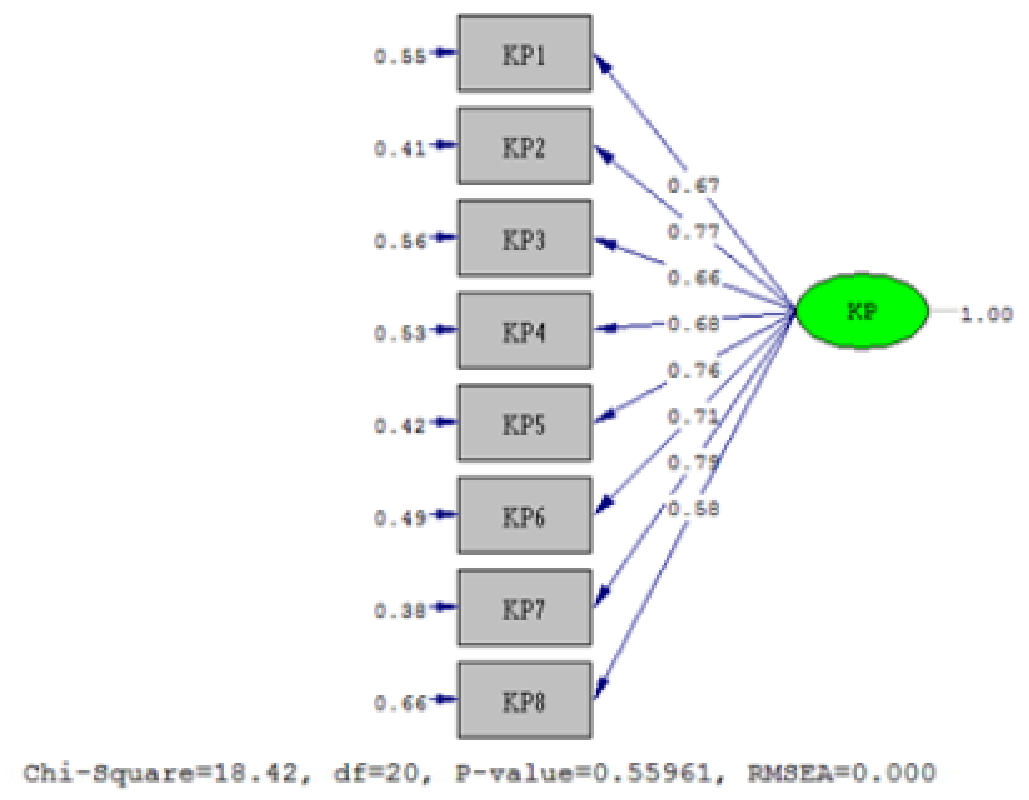

Table 4. Uji Validitas Variabel Kualitas produk

\begin{tabular}{|c|c|c|c|}
\hline Indicator & $\begin{array}{c}\text { SLF (Standardize } \\
\text { Loading Factor) }\end{array}$ & $\begin{array}{c}\text { Standard } \\
\text { Value }\end{array}$ & Information \\
\hline KP1 & 0.67 & \multirow{5}{*}{} & VALID \\
\hline KP2 & 0.77 & VALID \\
\hline KP3 & 0.66 & \multirow{4}{*}{0.50} & VALID \\
\hline KP4 & 0.68 & & VALID \\
\hline KP5 & 0.76 & & VALID \\
\hline KP6 & 0.71 & VALID \\
\hline KP7 & 0.79 & & VALID \\
\hline KP8 & 0.58 & & VALID \\
\hline
\end{tabular}

Source: Data processed with the 2018 Lisrel program

In Figure above, of the eight indicators processed in SEM, all of them are valid, in other words all indicators can be used in the research model.

c. Price

In this test, the attitude variable has been tested by getting the results Chi - Square $=0.000$; $\mathrm{df}=0$, Pvalue $=1,000$, RMSEA $=0,000$.

Figure.4 Price Variable Measurement Model

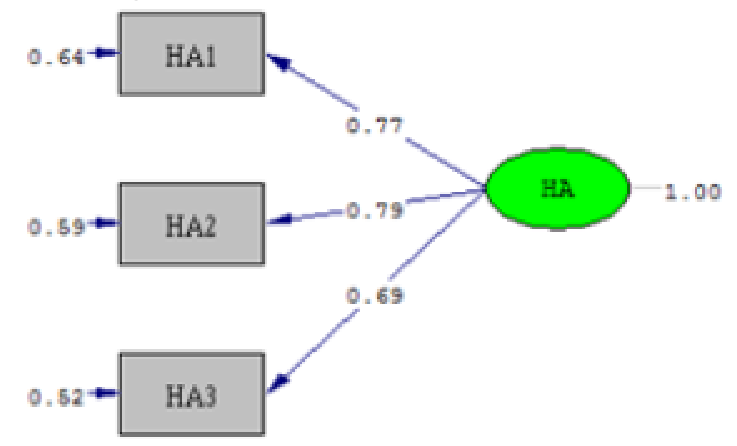

Chi-square $=0.00, d f=0, p-v a l u e=1.00000$, RMsEa $=0.000$ 
Table 5. Validity Test of Price Variables

\begin{tabular}{|c|c|c|c|}
\hline Indicator & $\begin{array}{c}\text { SLF (Standardize } \\
\text { Loading Factor) }\end{array}$ & \multirow{2}{\text{Standard}}{$\begin{array}{c}\text { Information } \\
\text { Value }\end{array}$} & \\
\hline HA1 & 0.77 & \multirow{2}{*}{0.50} & VALID \\
\hline HA2 & 0.79 & & VALID \\
\hline HA3 & 0.69 & & VALID \\
\hline
\end{tabular}

Source: Data processed with the 2018 Lisrel program

The three indicators processed in SEM are all valid, in other words all indicators can be used in the research model.

\section{d. Customer Satisfaction}

In this test, the attitude variable has been tested by getting the results Chi - Square $=0.000 ; \mathrm{df}=0$, Pvalue $=1,000$, RMSEA $=0,000$.

Figure 5: Customer Satisfaction Variable Measurement Model

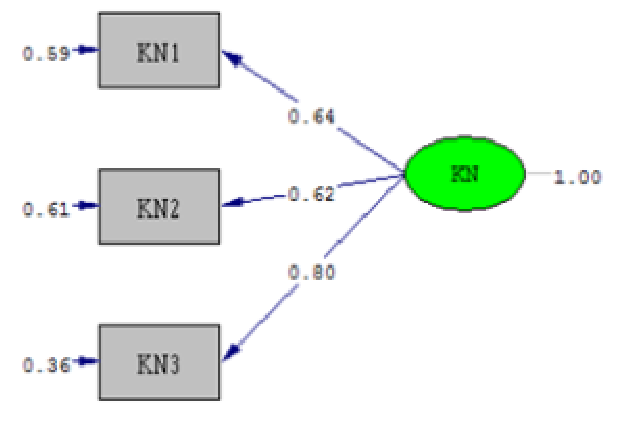

Chi-Sqquare $=0.00, d f=0, p-$ value $=1.00000$, RMSEA $=0.000$

Table 5. Validity Test of Customer Satisfaction Variables

\begin{tabular}{|c|c|c|c|}
\hline Indicator & $\begin{array}{c}\text { SLF (Standardize } \\
\text { Loading Factor) }\end{array}$ & \multirow{2}{*}{$\begin{array}{c}\text { Standard } \\
\text { Value }\end{array}$} & Information \\
\hline KN1 & 0.64 & \multirow{2}{*}{0.50} & VALID \\
\hline KN2 & 0.62 & \multirow{2}{*}{0.50} & VALID \\
KN3 & 0.80 & & VALID \\
\hline
\end{tabular}

Source: Data processed with the 2018 Lisrel program

All three indicators processed in SEM are declared valid.

\section{e. Reliability Test}

The reliability test in this study is calculated using construct reliability. The value of construct reliability $\geq 0.70$ indicates good reliability, while construct reliability is $0.60-0.70$ which can still be accepted on the condition that the validity of the model indicators is good [18]. A summary of the results of the reliability test on the variables of this study can be presented in Table 4.9.

Table 4.9 Reliability Test Results

\begin{tabular}{|l|c|}
\hline \multicolumn{1}{|c|}{ Variables } & Construct Reliability \\
\hline Quality of service & 0.869 \\
\hline Product quality & 0.887 \\
\hline Price & 0.795 \\
\hline Customer Satisfy & 0.730 \\
\hline
\end{tabular}

Source: Primary data processed, 2018

From the above calculations, it can be seen that all variables have a $C R$ value $>0.70$. Then the variable is declared reliable for use in research. 


\section{Measurement Model Fit Test}

\section{a. Measurement Model Fit Test}

The measurement model for the fit test of all variables in this study uses the SEM LIRSREL 8.8 application and the form of the measurement model is as follows:

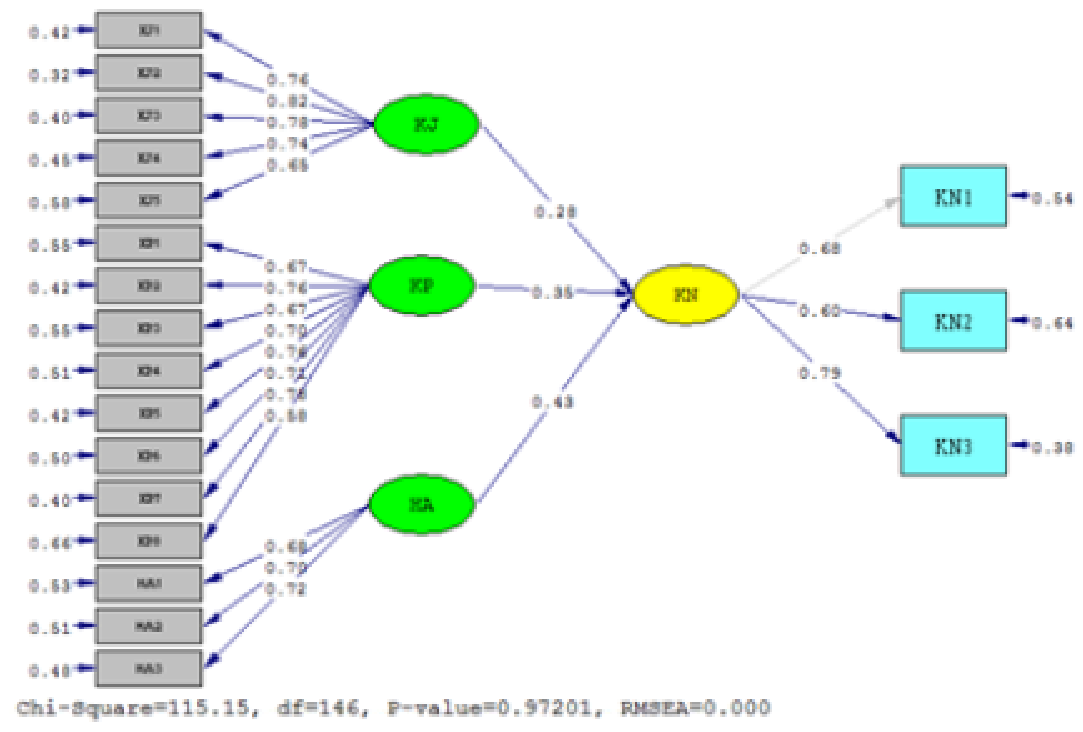

Figure.6 Overall Fit Test Measurement Model

Table 6. Overall Fit Test Results

\begin{tabular}{|c|c|c|c|c|}
\hline No & Size GOF & $\begin{array}{l}\text { Target match } \\
\text { rate }\end{array}$ & $\begin{array}{l}\text { Estimation } \\
\text { Results }\end{array}$ & $\begin{array}{c}\text { Match } \\
\text { Rate }\end{array}$ \\
\hline 1 & $\begin{array}{l}\text { Root Mean Square } \\
\text { Error of Appoximation } \\
\text { (RMSEA) }\end{array}$ & RMSEA $\leq 0,08$ & 0.00 & Good Fit \\
\hline 2 & $\mathrm{P}($ Close Fit $)$ & $P \geq 0,05$ & 0.97 & Good Fit \\
\hline 3 & Normal Fit Index (NFI) & $\mathrm{NFI} \geq 0,90$ & 0.94 & Good Fit \\
\hline 4 & $\begin{array}{l}\text { Non-Normal Fit Index } \\
\text { (NNFI) }\end{array}$ & $\mathrm{NNFI} \geq 0,90$ & 1.01 & Good Fit \\
\hline 5 & $\begin{array}{l}\text { Comparaive Fit Index } \\
\text { (CFI) }\end{array}$ & $\mathrm{CFI} \geq 0,90$ & 1.00 & Good Fit \\
\hline 6 & $\begin{array}{l}\text { Incremental Fit Index } \\
\text { (IFI) }\end{array}$ & $\mathrm{IFI} \geq 0,90$ & 1.01 & Good Fit \\
\hline 7 & Relative Fit Index (RFI) & $\mathrm{RFI} \geq 0,90$ & 0.93 & Good Fit \\
\hline 8 & $\begin{array}{l}\text { Goodnes of Fit Index } \\
\text { (GFI) }\end{array}$ & GFI $\geq 0,90$ & 0.89 & Marjinal \\
\hline 9 & $\begin{array}{l}\text { Adjusted Goodnes of Fit } \\
\text { Index (AGFI) }\end{array}$ & $\mathrm{AGFI} \geq 0,90$ & 0.86 & Marjinal \\
\hline
\end{tabular}

Source: Results of Processing with Lisrel 2018

From the table above, it can be seen that the constructs used to form a research model on the majority measurement meet the Good Fit criteria of the predetermined Goodness of Fit.According to Solimun in Arikunto[19] if one or more fit criteria have met, then the model can be said to be good. On this basis, it is concluded that this research model fulfills the goodness of fit and can be continued in further analysis, namely hypothesis testing. 


\section{b. T-Value Test Measurement Model and Research Hypothesis Testing.}

After determining the structural model with good Goodness Of Fit, the next step is to test the research hypothesis. In this study, there are three hypotheses described in chapter two, and testing was carried out to see the significance between variables. The estimated value of the causal relationship from the tested structural model is determined by the standard t table value $\leq-1.96$ or $\geq 1.96$. The following is the LISREL output from the results of hypothesis testing using the $t$ test:

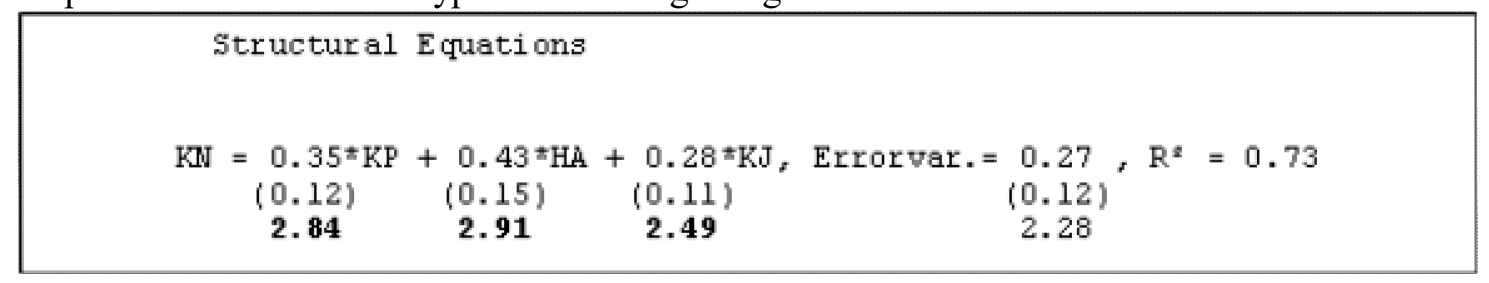

Based on this model, the hypothesis test results can be summarized as follows:

Tabel 4.11 Hypothesis Testing Results

\begin{tabular}{|c|c|c|c|c|}
\hline Hypothesis & Structural Path & T-Values & Information & Conclusion \\
\hline $\mathbf{H}_{1}$ & $\begin{array}{l}\text { Quality of service }\left(\mathrm{X}_{1}\right) \rightarrow \\
\text { Customer satisfaction }\left(\mathrm{Y}_{1}\right)\end{array}$ & 2,84 & $\begin{array}{l}\text { Hypothesis } \\
\text { accepted }\end{array}$ & $\begin{array}{l}\text { Service quality has a } \\
\text { significant positive effect } \\
\text { on customer satisfaction. }\end{array}$ \\
\hline $\mathbf{H}_{2}$ & $\begin{array}{l}\text { Product quality }\left(\mathrm{X}_{2}\right) \rightarrow \\
\text { Customer satisfaction }\left(\mathrm{Y}_{1}\right)\end{array}$ & 2,91 & $\begin{array}{l}\text { Hypothesis } \\
\text { accepted }\end{array}$ & $\begin{array}{l}\text { Product quality has a } \\
\text { positive effect on customer } \\
\text { satisfaction. }\end{array}$ \\
\hline $\mathbf{H}_{3}$ & $\begin{array}{l}\text { Price }\left(\mathrm{X}_{3}\right) \rightarrow \text { Customer } \\
\text { satisfaction }\left(\mathrm{Y}_{1}\right)\end{array}$ & 2,49 & $\begin{array}{l}\text { Hypothesis } \\
\text { accepted }\end{array}$ & $\begin{array}{l}\text { Price has a positive effect } \\
\text { on customer satisfaction }\end{array}$ \\
\hline
\end{tabular}

The results show that service quality has a significant positive effect on customer satisfaction, product quality has a positive effect on customer satisfaction, and price has a positive effect on customer satisfaction.

\section{Relationship Between Variables.}

\section{a. Hubungan Kualitas Jasa terhadap Kepuasan Nasabah.}

To win the competition, Islamic Commercial Banks in Bogor City must be able to provide good services to their customers. Increasing the quality of the services offered is getting more and more attention for companies, this is because the quality of services can be used as a tool to achieve a competitive advantage. In addition, improving the quality of good services can also lead to customer satisfaction and at the same time attracting new customers. This is very beneficial for the company, because through satisfying customer needs, customers will not look to other companies.

This can be seen from the results of the study that there is a relationship between service quality and customer satisfaction. It can be seen from the results of SEM analysis that it can be seen that service quality has a significant effect on customer satisfaction. This can be proven from the t-value of 2.84 , it can be said that there is an effect of service quality on customer satisfaction, so that $\mathrm{H} 1$ is accepted.

The results of this study have similarities with research conducted by Yulianti \& Kurniawan [20], which reveals that the variables of reliability, responsiveness, assurance, attention and real evidence simultaneously affect customer satisfaction at PT Kerta Gaya Pusaka Banjarmasin Branch. The five independent variables can explain the effect of service quality on customer satisfaction at PT Kerta Gaya Pusaka Banjarmasin Branch.

\section{b. Relationship of Product Quality to Customer Satisfaction}

Currently, customer satisfaction is considered important given the very competitive business conditions. The level of competition becomes high with various product differentiations. For companies, customer satisfaction is an important factor to increase profits. In addition, customer satisfaction is important for fostering good relations between the company and customers, so that long-term partnerships are established and ultimately customers are willing to make repeat purchases. For this reason, currently, to be able to win the competition, the company has begun to focus on increasing customer satisfaction. 
This can be seen from the results of the study that there is a relationship between product quality and customer satisfaction. It can be seen from the results of SEM analysis that it can be seen that product quality has a significant effect on customer satisfaction. This can be proven from the t-value of 2.91, it can be said that there is an effect of product quality on customer satisfaction, so that $\mathrm{H} 2$ is accepted.

\section{c. Price Relationship to Customer Satisfaction}

Every Islamic Bank is required to make customers feel satisfied by providing better offers and services. To win the competition, Islamic banks must be able to provide satisfaction to customers. Customer satisfaction is a customer's response to the mismatch between the previous level of interest and the actual performance that he feels after use. Customer satisfaction is determined by the quality of the goods or services the customer wants. So that quality assurance is a top priority for every Islamic Bank as a measure of excellence in the competitiveness of Islamic banks.

This can be seen from the results of the study that there is a relationship between price and customer satisfaction. It can be seen from the results of SEM analysis that it can be seen that price has a significant effect on customer satisfaction. This can be proven from the t-value of 2.49 , it can be said that there is an effect of price on customer satisfaction, so that $\mathrm{H} 3$ is accepted.

\section{CONCLUSION}

Based on the research results, there is a relationship between service quality and customer satisfaction. It can be seen from the results of SEM analysis that it can be seen that service quality has a significant effect on customer satisfaction, so it can be said that there is an effect of service quality on customer satisfaction, so $\mathrm{H} 1$ is accepted.

Based on the research results, there is a relationship between product quality and customer satisfaction. It can be seen from the results of SEM analysis that it can be seen that product quality has a significant effect on customer satisfaction, so it can be said that there is an effect of product quality on customer satisfaction, so that $\mathrm{H} 2$ is accepted.

Based on the research results, there is a relationship between price and customer satisfaction. It can be seen from the results of SEM analysis that it can be seen that price has a significant effect on customer satisfaction, so it can be said that there is an effect of price on customer satisfaction, so that $\mathrm{H} 3$ is accepted.

\section{REFERENCES}

[1] Cahyani, PD dan Utami, RF. 2016. Analisis Kinerja Pada Bank Umum Syariah Devisa Di Indonesia Ditinjau Dari Maqasid Syari'ah (Pendekatan Syari'ah Maqasid Index /Smi). Prosiding ISBN: 978-602-361-041-9, Seminar Nasional \& Call For Paper - Riset Manajemen \& Bisnis 2016 "Pendekatan Keperilakuan Dalam Riset Manajemen \& Bisnis"

[2] Ngatmo, TB. 2012. Faktor-Faktor Yang Mempengaruhi Kepuasan Pelanggan Pada PT. Sido Muncul Semarang. Jurnal Kajian Akuntansi dan Bisnis, Vol 1, No 1.

[3] Purnaningsih, Retna Brata. 2008. Faktor-Faktor yang Mempengaruhi Kepuasan Nasabah di PD. BPR BKK Jepara. Skripsi Sarjana Jurusan Manajemen pada Fakultas Ekonomi Universitas Negeri Semarang, Semarang.

[4] Kotler, Philip dan Armstrong, Gary. (2011). 10th Edition."Marketing an Introduction”. Indonesia: Perason.

[5] Kaniganat \& Chaipoopirutana. 2014. A Study of Factors Influencing Customer Satisfaction: An Implementation on Thai Postal Service, Bangkok Area. International Conference on Business, Law and Corporate Social Responsibility (ICBLCSR'14) Oct 1-2, 2014 Phuket (Thailand)

[6] Molaee, Maysam., Ansari, Reza., Teimuori, Hadi. (2013). Analyzing the Impact of Service Quality Dimensions on Customer Satisfaction and Loyalty in the Banking Industry of Iran. International Journal of Academic Research in Accounting, Finance and Management Sciences, Vol. 3, No.3, July 2013, pp. 1-9

[7] Sumarwan, Ujang. 2011. Perilaku Konsumen: Teori dan Penerapannya dalam. Pemasaran. Bogor: Ghalia Indonesia.

[8] Kotler, Philip. 2000. Prinsip - Prinsip Pemasaran Manajemen, Jakarta : Prenhalindo.

[9] Sarirati, P dan Fitria, KN. 2018. Pengaruh Pelayanan Email Care Center Terhadap Kepuasan Nasabah PT. Mandiri Sekuritas Pada Tahun 2016.Prosiding Festival Riset Ilmiah Manajemen \& Akuntansi. Hal 894-902 
[10] Mohsen, et al. 2013. "The Examining Mathematical Word Problems Solving Ability Under Efficient Repesentation Aspect”. Journal of Mathematics Education Trends and Research 2013.

[11] Hidayat, Rachmat. (2009). Pengaruh Kualitas Layanan, Kualitas Produk dan Nilai Nasabah Terhadap Kepuasan dan Loyalitas Nasabah Bank Mandiri. Jurnal Manajemen Dan Kewirausahaan. Vol.11, No. 1.

[12] Kartika, Tika. 2016. Analisis Faktor-Faktor yang Mempengaruhi Loyalitas Nasabah pada Bank Umum Syariah Studi Kasus Bank Umum Syariah di Kota Bogor. Tesis: STEI TAZKIA.

[13] Panjaitan dan Yuliati. 2016. Pengaruh Kualitas Pelayanan Terhadap Kepuasan Pelanggan Pada Jne Cabang Bandung. DeReMa Jurnal Manajemen Vol. 11 No. 2

[14] Noerchoidah. 2017. Pengaruh Kualitas Pelayanan Jasa Terhadap Kepuasan Pelanggan (Studi Orenztaxi Di Surabaya). Bisnis dan Manajemen - Volume 9 No 2.

[15] Sugiyono. 2010. Metode Penelitian Kuantitatif Kualitatif \& RND. Bandung: Alfabeta.

[16] Otoritas Jasa Keuangan. 2016. Laporan Perkembangan Keuangan Syariah 2016. Diakses pada tanggal 04 Oktober 2018, https://www.ojk.go.id/id/berita-dan-kegiatan/publikasi/Documents/Pages/LaporanPerkembangan-Perbankan-dan-Keuangan-Syariah2016/Laporan\%20Perkembangan\%20Keuangan\%20Syariah\%20(LPKS)\%202016.pdf

[17] Wijanto. 2008.Multivariate analysis techniques that allow researchers to examine the relationships between complex variables to obtain a comprehensive picture of the overall model. SEM was developed to cover the limitations of models such as: regression analysis, path analysis, and confirmatory factor analysis

[18] Ghozali, Imam. 2008. Aplikasi Analisis Multivariate dengan Program SPSS. Semarang: Badan Penerbit Universitas Diponegoro.

[19] Arikunto, Suharsimi. (2010). Prosedur penelitian: Suatu Pendekatan Praktik. (Edisi. Revisi). Jakarta : Rineka Cipta.

[20] Yulianti, F., \& Kurniawan, I. N. F. (2016). PENGARUH KUALITAS JASA TERHADAP KEPUASAN PELANGGAN PADA PT KERTA GAYA PUSAKA CABANG BANJARMASIN. JURNAL ILMIAH BISNIS dan KEUANGAN, 1(1). 